\title{
Macrothink

\section{Psychosocial Wellbeing of Genocide Widows in Rwanda through Their Associations: A Case Study of Avega in Rwimbogo Sector}

\author{
Bayisenge Ernestine (Corresponding author) \\ University of Technology and Art of Byumba (UTAB), Faculty of Social Sciences, \\ Management and Development Studies \\ Department of Social Sciences, Option of Social Work \\ E-mail: bayistine@yahoo.fr Tel: 250-788-436-631
}

Received: March 30, 2016 Accepted: June 24, 2016 Published: June 27, 2016

doi:10.5296/ijsw.v3i2.89666 URL: http://dx.doi.org/10.5296/ijsw.v3i2.9666

\begin{abstract}
The research conducted on the role of associations of genocide widows was undertaken with the purpose of determining the contribution of Association of Widows of Genocide in Rwanda (AVEGA) in addressing the problems of widows of genocide in Rwanda and improving their wellbeing. The results of investigation carried out on 72 genocide widows through a questionnaire revealed that AVEGA improves the wellbeing of widows with the promotion of good health by providing medical services to them, the economic development by introducing activities which generate income in order to eradicate poverty, establishment of good relationship by encouraging the national policy of unity and reconciliation among Rwandans and supporting children in their studies.
\end{abstract}

Keywords: Associations, Genocide widows, Psychosocial wellbeing, Rwanda

\section{Introduction}

Genocide is a crime that has been committed throughout the ages. It is recognized as a problem of international concern as it affects vital interests of all civilized people.

Totten and Bartrop (2009) agreed that the genocide concerns and potentially affects all people. Its consequences can neither be isolated nor localized. Heidenrich (2001) added that more than a crime against any particular people, genocide is the ultimate crime against humanity because it violates the rights of individual and the group and off all humankind simultaneously.

In April 1994, Rwanda fell into genocide that brought about one million of victims and caused immeasurable social problems. According to Berry (1999) "the genocide affected 
the entire population of Rwanda. Everyone alive in Rwanda has a story to tell about the genocide."

Genocide affected mostly women. Before the genocide, in Rwanda, all responsibilities were fulfilled by men: Women did not have a role in the decision making process, their role was only taking care of children and their husbands. So, women are powerless to resist the genocide consequences as they stay with only orphans. J. A. and C. P. Berry (1999) noted that it is women who feel the terrible consequences of genocide, massacre and war. They are largely unprepared to assume the new responsibilities that fall on their back. The author added that the women of Rwanda fear tomorrow because of the number of people who depend on them (their own children, family members and others who escaped the genocide).

In addition, many women were raped during genocide. The UN estimates that in Rwanda there were between 250000 and 500000 rapes (Totten \& Parson, 2009). Hutu militiamen raped Tutsi women across the country during genocide. HIV/AIDS and unwanted pregnancies are the consequences of the act of rape. The majority of rape survivors are HIV positive and others are obliged to take care of children born from rape. Those problems prevent women from ensuring an adequate standard of living for them and their children.

To address those problems, widows formed associations including "AVEGA" in order to help each other to overcome these problems. It is upon this situation that the researcher seeks to examine the role of AVEGA in improving the wellbeing of its members.

\section{Research Methodology}

The study adopted quantitative research method of data collection. Data of the study was collected from primary and secondary sources (Marlow, 2001). Primary data was obtained from a sample through survey method while secondary data was gathered from published and unpublished research reports, journals, books, as well as from records and other documentation agencies. For data collection, a questionnaire was administrated to 72 widows survivors of the genocide in Rwanda living in Rwimbogo Sector, members of AVEGA and they were chosen on the basis of purposive sampling. This area was chosen as a village which counts a big number of widows of genocide. AVEGA is a non-profit organization created on $15^{\text {th }}$ January 1995 and approved by Ministerial decree $n^{\circ} 156 / 05$ on $30^{\text {th }}$ October 1995. Furthermore, all women whose husbands were killed during genocide in Rwanda, April 1994, were considered as the population of the study. Then, the collected data from the research area was analyzed. The records were reviewed to get descriptive statistics and presented according to emerged themes.

\section{Overall Findings}

\subsection{Demographic Features}

The respondents are old widows as this research concerned only women who were married before genocide perpetrated against Tutsi, April 1994. Between 70-60 years of old were $42 \%$ of all respondents while those between $80-70$ represented $21 \%$.

The respondents were living in rural area, $83.4 \%$ of them were farmers and $72 \%$ had only primary school education. Illiterate members were $15 \%$ of the respondents. The low level 
of education increases their vulnerability because it is difficult for them to find a good job in order to satisfy their needs.

\subsection{Events Experienced by Widows during the Genocide}

The study of Taylor (1999) found that in 1994, Rwanda has known terrible events where about one million people were murdered in three months only.

\subsubsection{Killings Witnesses}

All respondents (100\%) lost their husbands during the genocide. About 97\% lost their children and $9.7 \%$ of widows are survivors with no kid. Other close relatives $(86.1 \%)$ were also killed. They were in churches, schools and hospitals. The study of J. A. Berry and C. P. Berry (1999) found that the church suffered greatly during the genocide in Rwanda. People took refuge in churches and monasteries because they thought that no one could enter, in the church to killing. Other victims of genocide were thrown into rivers or toilet pits $(16.6 \%)$ while others were burned alive in houses $(12.5 \%)$. The results indicated that widows witnessed the brutal killings genocide victims and they did not bury them.

\subsubsection{Difficulties Faced by Widows during Genocide in Rwanda}

The widows of genocide experienced all sorts of torture: $83.3 \%$ of respondents agreed that they were beaten during the genocide, $63.8 \%$ have been injured and $13.8 \%$ present now physical handicap. The widows raped represent $9.7 \%$. The study of Totten and Bartrop (1999) found that the rape of women and girls constitutes yet another form of dehumanization. In Rwanda, women were raped by large groups of soldiers and militia. They did the most they could to humiliate the women, raping her in front of her husband and children. Women and young girls were also taken away and locked up in homes by militia as their private property. The militia member would then come back and rape the women or girls whenever he wanted. Some women were mutilated and cannot be proud of their own bodies any longer.

\subsubsection{Escaping from Killings}

Widows survived because they were hidden by their friends who were Hutus. African Rights (2002) stated that during the genocide, some Hutus tried to save Tutsis sometimes successfully. Other widows spent days and nights in forests where they suffered from hunger, cold climate, and other causes of health problems. About $23.6 \%$ of widows were hidden under dead bodies; they were with many persons and when they were murdered, killers realized that those widows also died as they were all covered with blood and sometimes injured. Around $6.9 \%$ of widows have been hidden by their rapists as they wanted to rape them anytime they wanted.

\subsection{The Present Living Condition of Genocide Widows in Rwanda}

"When you see women who have survived to genocide, you must realize that they have many problems (J. A. Berry \& C. P. Berry, 1999)". Widows are facing different problems as a result of genocide.

\subsubsection{Health Problems}

The experiences of widows are causes for trauma in Rwimbogo Sector. All widows $100 \%$ who participated in the research show different symptoms of trauma such as nightmares, flashbacks, etc. Poor sanitation is also another issue for widows of genocide. It represents 
$90.2 \%$, this is due to the lack of clean water in rural regions in Rwanda and widows who don't have children use dirty water (like water from wetlands) because they do not have the strength to fetch clean water. Widows of genocide also have problem of hunger/malnutrition (55.5\%) because of the shortage and unfertile of land whereas they do not have any other job so that they could find money for surviving. $6.9 \%$ of respondents are HIV/AIDS positive due to rape done to widows during the genocide. Totten and Bartrop (2009) agreed that a uniquely Rwanda component of rape in genocide was the deliberate transmission of HIV. They added that according to witnesses, Hutu rapists said that they had HIV and wanted to give it to the victims so that they could die slowly from AIDS. In Rwanda, the physiological and psychological complications of rape led many rape survivors to say that they would rather have been killed. The findings show that respondents suffer from other different diseases (stomachache, headache, etc.) because of many problems they experience in their daily life.

\subsubsection{Economic Problems}

The results of the study show that widows of genocide in Rwanda present different economic problems: $80.5 \%$ are poor, $76.3 \%$ have lack of household necessities like food, etc. Findings showed that $55.5 \%$ are homeless because their houses were destroyed during genocide and $44.4 \%$ don't have any job, they didn't study, they do not have land to cultivate and they do not have money to do other business. Other widows have the problems of different kinds like heritage problems because they haven't been married legally with their dead husbands. Those widows and their children are not recognized by the husbands' family.

\subsubsection{Relationship Problems}

All widows who participated in the study have felt isolated (100\%). Around $97.2 \%$ of widows of genocide have anger toward killers while $93 \%$ of widows experience fear. Mistrust represents $84.7 \%$ and other behaviors like hate, etc. represent $58.3 \%$. These behaviors are explained by the views of Tottens and Bartrop (2009). They said: "trauma creates mistrust, disconnection, and insecurity to people."

\subsection{The Promotion of Welfare of AVEGA Members}

AVEGA seeks to promote the general welfare of widows through social and economic development projects, legal advocacy, training and other supports that contribute to the income generation and self-sufficiency. It also operates three health centers and provides medical services to widows.

\subsubsection{Assistance in Health Care}

Considering the findings of the study, all widows (100\%) agreed to benefit from trauma counseling sessions for themselves or for their children. Also, all widows (100\%) accepted that medical services are provided. For $90.2 \%$ of those widows have health insurance. AVEGA also supports VIH/AIDS positive widows, $6.9 \%$ are taking antiretroviral treatment, material supports like food are given to them. In short, AVEGA focuses on health and social problems faced by widows; they have programmes and trained staff who aim to treat the medical and psychological effects of trauma. 


\subsubsection{The Economic Development Sustainability}

As for the role of AVEGA in economic development of its members, AVEGA offers financial assistance and aims to empower AVEGA members. It tries to help their members replace housing and infrastructure destroyed during the genocide. The association built houses for 32 widows; $44.4 \%$ of genocide widows are living now in those houses. $62.5 \%$ of those widows have cows given by the association and $23.6 \%$ were given loans in order to do small business. Findings showed that $16 \%$ of those widows are doing some activities which generate income like basket-weaving and other types of handcraft.

\subsubsection{Restoring Unity and Reconciliation}

Findings showed that $84.7 \%$ of our respondents agreed that AVEGA helped them to forgive the killers due to different trainings on peace building, unity and reconciliation. $62.5 \%$ of widows who participated in our research are assisted in the memory of the genocide victims while $34.7 \%$ are also assisted in courts by AVEGA. Kriesberg's (2001) defined the concept of reconciliation as "the process by which parties that have experienced an oppressive relationship, or a destructive conflict, with each other move to attain or to restore a relationship that they believe to be minimally acceptable".

The word reconciliation in Kinyarwanda is ubwiyunge. It comes from the same root used to describe setting a broken bone. This Rwandan concept means bringing together people whose relations have been ruptured. Reconciliation is the fact that those who did wrong ask forgiveness from those whom they offended and thus the two parties renew their social relations as before.

AVEGA' members were encouraged to pardon killers so that trauma healing should take place. According to Hamber (2003), apologies, if they are sincere, can contribute to individual and community healing. Widows agreed that they have forgiven the killers. This increased good relationship with them so that intermarriage was restored or participate in each other's ceremonies.

AVEGA strives for justice for its members. It assists widows who wish to testify against those accused of genocide. Members are accompanied to court and receive assistance by AVEGA in killers' prosecution.

Concerning commemoration of victims, the government of Rwanda organizes one week commemoration period of the Tutsi Genocide from 7th - 13th April of every year. During this period, the association meditates deeply on the genesis, planning, and execution of the genocide. This is also a period to look at the effects of the genocide and the measures to curb them; measures to fight against genocide ideology and support to the genocide survivors.

The main purpose of commemoration of genocide victims is burial in dignity of the remains of victims of the Tutsi Genocide in the whole country, to promote the culture of peace, unity and reconciliation and to rehabilitate memorial sites. AVEGA is involved in those activities and assists members during that period by giving them time of testimonies so that they could express their emotional feelings. In that case, trauma healing process is possible, and then reconciliation can take place.

\subsubsection{Contribution of AVEGA in Education for Orphans}


AVEGA does not deal with only the widow's problems but also those of their children especially in their education. The results of the study revealed that AVEGA pays fees in vocational schools as agreed by $66.6 \%$ of our respondents. Also, $47.2 \%$ of widows accepted that the association provides school materials such as pens, uniforms, books for their children while $34.7 \%$ agreed that their children are assisted by paying transport fees for going and coming from schools. Before they got this assistance, most of the orphans were school dropouts due to shortage of financial means.

\subsection{Appreciation of the Support from AVEGA}

Considering the findings of the research, $90.2 \%$ of widows stated being in good health due to AVEGA by providing different health services to them. $69.4 \%$ are now able to satisfy their basic needs as they are engaged in activities which generate incomes like business, handcraft, etc. $66.6 \%$ accepted that their children are studying from the help of AVEGA and $58.3 \%$ of widows have increased trust in others due to trauma healing sessions and the process of reconciliation organized by AVEGA. 58.3\% have a hope for the future when they consider their living conditions just after being members of AVEGA.

\section{Conclusion}

The genocide in Rwanda has left behind it immeasurable consequences. Most survivors are widows who are living in critical conditions. They experience health and socioeconomic problems like poverty, lack of household necessities, and the relationship problems among them isolation and anger. The association (AVEGA) is dealing with those problems in order to improve the welfare of widows. The outcome of analysis and interpretation of data proved that AVEGA plays a great role in improving the living standards of widows as it was indicated that after being members of that association those widows are able to satisfy their basic needs. Widows who had been traumatized by the genocide and left without any hope of ever again leading productive lives, have now regained significant self-esteem, and with it a far more positive outlook on the future.

\section{References}

African Rights. (1995). Rwanda: Death, despair and defiance: London.

African Rights. (2002). Tribute to courage. Kigali: Rwanda.

Ahuja, R. (2001). Research Methods. Nice printing press: New Delhi.

Berry, J. A., \& Berry, C. P. (1999).Genocide in Rwanda, a collective memory: Washington DC: Howard University Press.

Hamber, B. (2003). Healing, Reconciliation after violent conflict: Institute for Democracy and ectoral Assistance.

Heidenrich, J. G. (2001). How to prevent genocide: a guide for Policymakers, Scholars, and the concerned Citizen, Westport, Connecticut.

Ederah, J. P. (19997). Building peace: sustainable reconciliation in divided societies. Washington DC, Institute of peace press

Kriesberg, L. (2001). Changing forms of coexistence, Reconciliation, justice, and coexistence: theory and practice. Lanham, ML: Lexington Books.

Marlow, C. (2001). Research methods for Generalist Social Work, Belmont, Wadswort/Thomson Learning, New York. 
Taylor, C. C. (1999). Sacrifice as Terror: The Rwandan Genocide of 1994. Oxford: Berg.

Totten, S., \& Bartrop, P. R. (2009). The genocide studies readers, New York: London

Totten, S., \& Parsons, W. S. (2009). Century of Genocide: Critical essay \& Eyewitness accounts. New York: London

Tutu, D. (1999). No future without forgiveness. USA: New York.

Walter, W. (1998). When the power falls: reconciliation in the healing of nation, Minneapolis: Fortress Press.

\section{Glossary}

AVEGA: Association des Veuves du Genocide au Rwanda Agahozo (Association of widows of Genocide in Rwanda.

HIV/AIDS: Human Immunodeficiency Virus/Acquired Immune Deficiency Syndrome.

\section{Copyright Disclaimer}

Copyright reserved by the author(s).

This article is an open-access article distributed under the terms and conditions of the Creative Commons Attribution license (http://creativecommons.org/licenses/by/3.0/). 